\title{
Yield, seasonality and plant health care of banana 'BRS Conquista' covered with different coloured polyethylene bags
}

\section{Rendimento, sazonalidade e fitossanidade dos frutos de bananeira 'BRS Conquista' ensacados com polietileno de diferentes colorações}

\author{
Rafaelly Calsavara Martins ${ }^{1 *}$; Sarita Leonel ${ }^{2}$; Jackson Mirellys Azevêdo Souza ${ }^{3}$; \\ Marcelo de Souza Silva ${ }^{1}$; Rafael Bibiano Ferreira ${ }^{1}$; Patrícia Graosque Ulguim \\ Züge $^{1}$; Emi Rainildes Lorenzetti ${ }^{4}$; Regiane Cristina Oliveira de Freitas Bueno ${ }^{5}$
}

\author{
Highlights: \\ The covering of banana bunches did not interfere in the plant yield. \\ The interval between bunch covering and harvest was reduced in white and black bags. \\ Covering banana bunches with white and red bags reduces damage to thrips. \\ White, red and blue polyethylene bags promoted a lower incidence of anthracnose. \\ It is recommended to use plastic bags to produce quality fruits.
}

\begin{abstract}
Bananas are the world's most popular fruit. Nonetheless, a great part of the production is lost, mainly for insect and disease incidences. Thus, cover developing banana bunches is a promising physical protection method that will improve the visual quality of the fruits, especially the rapidly growing consumer demand for healthy fruits. In fact, bags serve as protective barrier, allowing the production of free fruit damage; consequently, lowering production costs by cutting crop losses, as well as avoiding chemical materials. There is a wide variety of bag types and colours, but also, there is a scarce literature on their efficiency. This study hence aimed to evaluate the influence of coloured polyethylene bags on yield, seasonality and plant health of the 'BRS Conquista' bananas in subtropical high-altitude growing conditions. Treatments therefore consisted of using white, black, red and blue polyethylene bags, besides control (uncovered). Then, bags were randomly distributed in five blocks, four plants per plot. After bunch harvest, the following evaluation were proceeded: agronomic yield, the interval between bunches cover and harvest, injuries caused by thrips and the incidence of anthracnose. Results indicated that banana bunch coverings did not interfere in bunch yield. Nevertheless, white and black bags reduced the interval between bunch covers and harvest, that is, 114 and 115 days, respectively. Furthermore, white and red bags reduced the damage caused by thrips in fruits; while white, red and blue bags decreased the anthracnose incidence. This study therefore recommends the use of white polyethylene bags to cover banana bunches of the cultivar BRS Conquista, since this bag colour showed highly efficiency
\end{abstract}

\footnotetext{
${ }^{1}$ Discentes do Curso de Doutorado do Programa de Pós-Graduação em Agronomia/Horticultura, Departamento de Horticultura, Faculdade de Ciências Agronômicas, Universidade Estadual Paulista, UNESP, Botucatu, SP, Brasil. E-mail: rcalsavara@yahoo. com.br; mace-lo-souza@hotmail.com; aprigio_bibiano@hotmail.com; graosque@yahoo.com.br

2 Prof ${ }^{a}$ Dra , Programa de Pós-Graduação em Agronomia/Horticultura, Departamento de Horticultura, UNESP, Botucatu, SP, Brasil. E-mail: sarita.leonel@unesp.br

3 Pós-Doutorando do Programa de Pós-Graduação em Agronomia/Horticultura, Departamento de Horticultura, UNESP, Botucatu, SP, Brasil. E-mail: jackson.mirellys@hotmail.com

4 Prof $^{a}$ Dr $^{\mathrm{a}}$, Instituto Federal do Paraná, Campus Campo Largo, PR, Brasil. E-mail: emi.lorenzetti@ifpr.edu.br

5 Prof $^{\mathrm{a}}$ Dra $^{\text {a }}$, Programa de Pós-Graduação em Agronomia/Proteção de Plantas, Departamento de Proteção de Plantas, UNESP, Botucatu, SP, Brasil. E-mail: regiane.bueno@unesp.br

Authr for correspondence
}

Received: Apr. 14, 2020 - Approved: June 02, 2020 
in controlling thrips and anthracnose incidence, besides reducing the interval between bunch cover and harvest.

Key words: Crop management. Banana bunch cover. Musa sp. Frankliniella brevicaulis. Colletotrichum musae.

\section{Resumo}

Bananas são as frutas mais populares do mundo, porém a incidência de insetos e de doenças provoca muitas perdas de frutos. Neste sentido, o ensacamento dos cachos torna-se uma técnica promissora, sobretudo diante da crescente exigência dos consumidores por frutos de qualidade e seguros do ponto de vista alimentar. Os sacos funcionam como barreira de proteção, permitindo a produção de frutos livres de danos, com consequente redução de perdas e dos custos com aplicações de produtos químicos. Contudo, existe uma grande variedade de tipos e cores de sacos no mercado, mas não há relatos sobre a interferência destes parâmetros sobre a eficiência do ensacamento. Portanto, este estudo objetivou avaliar a influência do uso de sacolas de polietileno, com diferentes cores, sobre o rendimento, sazonalidade e fitossanidade dos cachos da banana 'BRS Conquista' cultivada em região subtropical de alta altitude. Os tratamentos consistiram na utilização de sacos de polietileno branco, preto, vermelho e azul, além do controle (sem ensacamento). Estes sacos foram distribuídos aleatoriamente em cinco blocos e quatro plantas por parcela. Após a colheita dos cachos, avaliou-se o rendimento agronômico, o intervalo entre a emissão do cacho e a colheita e a presença de danos de tripes, além do avanço da incidência de antracnose até a maturação dos frutos. A partir dos resultados, verifica-se que o ensacamento não interferiu no rendimento dos cachos. Porém, a utilização de sacos brancos (114 dias) e pretos (115 dias) reduziram o intervalo entre o ensacamento e a colheita. Os sacos brancos e vermelhos reduziram os danos provocados pelos tripes nas frutas; enquanto sacos brancos, vermelhos e azuis diminuíram a incidência de antracnose. Portanto, recomenda-se o uso de sacos de polietileno branco para coberturas de cachos de banana 'BRS Conquista', devido à maior eficiência no controle de tripes e antracnose; além de diminuir o intervalo de tempo entre a emissão do cacho e a colheita.

Palavras-chave: Manejo de culturas. Ensacamento de frutos. Musa sp. Frankliniella brevicaulis. Colletotrichum musae.

\section{Introduction}

Regardless the health benefits presented in banana fruits, there are also social and economic importance since bananas (Musa spp.) are within the world's most produced fruits. In this sense, India was placed at $1^{\text {st }}$ position among many countries regarding banana production; and Brazil was at $4^{\text {th }}$ position and produced at 6.75 million tons in 2018 (Food and Agriculture Organization [FAO], 2020).

Although bananas are largely consumed in the world, they also have enormous losses in each step of the production (Souza, Leonel, \& Fragoso, 2011). Among the losses, there are the insect attacks in the pre-harvest, causing peel damage. In areas of high insect infestation, growers are challenged in producing blemish-free fruits, resulting in significant losses in quality, thereby impairing commercialization (Santosh, Tiwari, \& Reddy, 2017).

Thrips cause superficial skin blemishes on both immature and developing banana fruit. Frankliniella bispinosa Morgan is a common flower thrips, and this causes a small raised pimple capped by a black spot that will be developed on the fruits surface, because the adult female insects lay their eggs on immature fruits (PROMUSA, 2018). Such damages increase losses in fruit quality and decreases their commercial value, though they do not interfere with the organoleptic characteristics of them (Fancelli \& Mesquita, 2012). 
The thrips infection in banana fruits also facilitates the proliferation of post-harvest fungal rots, such as Colletotrichum musae, which is an important pathogen causing banana anthracnose (Brown, William, \& Khamphoukeo, 2013; Parisi, Henrique, \& Prati, 2015). This disease can cause losses of up to $40 \%$; therefore, commercialization of fresh fruits is mainly affected due to development of dark spots on the fruit skin. Furthermore, banana fruits spoiled by this fungus can cause reduced shelf life of the sound fruits due to accelerated ripening (Mirshekari, Ding, Kadir, \& Ghazali, 2012).

There is a need to reduce the damage caused by thrips, and consequently by anthracnose. Therefore, some strategies are commonly used by producers, such as removing the banana heart (male inflorescence) and spraying insecticides above bunches (Fancelli \& Mesquita, 2012). However, consumers are increasingly motivated to be more environmentally conscious and are exercising their power and voice through the products they buy; there is therefore a need in developing attractive and environmentally friendly alternative techniques to improve appearance and internal fruit quality and to reduce disease and insect infestation (Vargas, Valle, \& González, 2010) consequently, using less pesticides to ensure worker safety, consumer health, and environmental protection (Santosh et al., 2017).

Hereupon banana bunch cover is within the potential practices for reducing the incidence of disease, insect and/or mechanical damage (Fancelli \& Mesquita, 2012). Amani and Avagyan (2014) also reported that bunch covering is an efficient and recommended technique in preventing and controlling fungal infections, such as anthracnose. In addition to the plant health care, bunch covering protects fruits against mechanical damages caused by rain, cold, winds and banana leaf friction (VargasCalvo \& Valle-Ruiz, 2011). Banana bunch covering is a fairly common practice among producers, but there are some problems that are needed to be solved (Santosh et al., 2017), such as choosing the color and material that best meet each producing region needs (Muchui et al., 2010; PROMUSA, 2018).

Different coloured bags and conditions (i.e. perforated and non-perforated) have been extensively used in both tropical and subtropical banana producing countries. Bunch covers are easy to find and generally are white or translucent blue, but also transparent cover let more light in than the blue colour. Blue covers let in $73 \%$ of the wavelengths in the photosynthetically active radiation (PAR), whereas transparent ones let in 93\%. Nevertheless, blue covers produce heavier bunches because it lets in the heat without causing burns as it blocks UV rays (Santosh et al., 2017).

The bunch cover recommendations differ accordingly to the producing regions around the world. Santosh et al. (2017) stated that plastic can be of different colours and may vary according to the climate type in each region. Thus, studies are needed to subside information on the most suitable colour for a given region, these joint studies can therefore improve fruit quality by reducing the incidence of thrips and anthracnose around the world, besides reducing costs related to insecticides application.

Such technique has to be tested with banana cultivars that possess superior traits, such as 'BRS Conquista' (AAB - Prata group), a recently released genotype with high productive performance and resistance to Black and Yellow Sigatoka, as well as Panama disease (Pereira \& Gasparotto, 2008; Smith, Langdon, Pegg, \& Daniells, 2014). Thus, this study aimed to evaluate the influence of different colored bags on yield, bunch emergence to harvest interval and plant health care of banana cv. BRS Conquista in subtropical high-altitude growing conditions.

\section{Material and Methods}

Location and characterization of the experimental area

The experiment was performed at the Experimental Orchard for the School of Agriculture 
(FCA/UNESP), located in the city of Botucatu, São Paulo $\left(22^{\circ} 51^{\prime} 55^{\prime \prime} \mathrm{S}, 48^{\circ} 27^{\prime} 22^{\prime \prime} \mathrm{W}\right.$, at an altitude of $810 \mathrm{~m})$. According to the Köppen climate classification, the area is classified as Cwa, that is, temperate hot (mesothermic). The hottest month in Botucatu has an average temperature of $22{ }^{\circ} \mathrm{C}$ (Cunha \& Martins, 2009). The soil of the area is classified as a typical Dystrophic Red Latosol (Embrapa Empresa Brasileira de Pesquisa Agropecuária [EMBRAPA], 2006).

The banana 'BRS Conquista' was planted in January 2015 , spaced at $2.5 \times 2.0 \mathrm{~m}$, in a non-irrigated system. All cultural practices recommended for the crop were followed, such as weed control after planting and senescent leaves removal. Furthermore, we use a traditional cultivation method for banana, as three plants were left in each clump, remaining plants were thinned, and removing the banana heart 15 days after the inflorescence emission.

\section{Bagging for banana bunch covers}

The experiment was carried out from October 2016 to September 2017, that is, in the second production cycle. The treatments consisted of uncovered bunches and covered with white, red, blue and black polyethylene bags (Figure 1). All the plastic bags were made from polyethylene, $150 \mathrm{~cm}$ long $\times 75 \mathrm{~cm}$ wide, open at both ends and $0.5 \mathrm{~cm}$ perforation in the lateral to allow gas exchange between fruits and external environment. The bagging of banana bunches started when inflorescences emitted until they opened their bracts (Santosh et al., 2017; PROMUSA, 2018). The bags were set on the upper edge of the rachis, knotting their own ends.

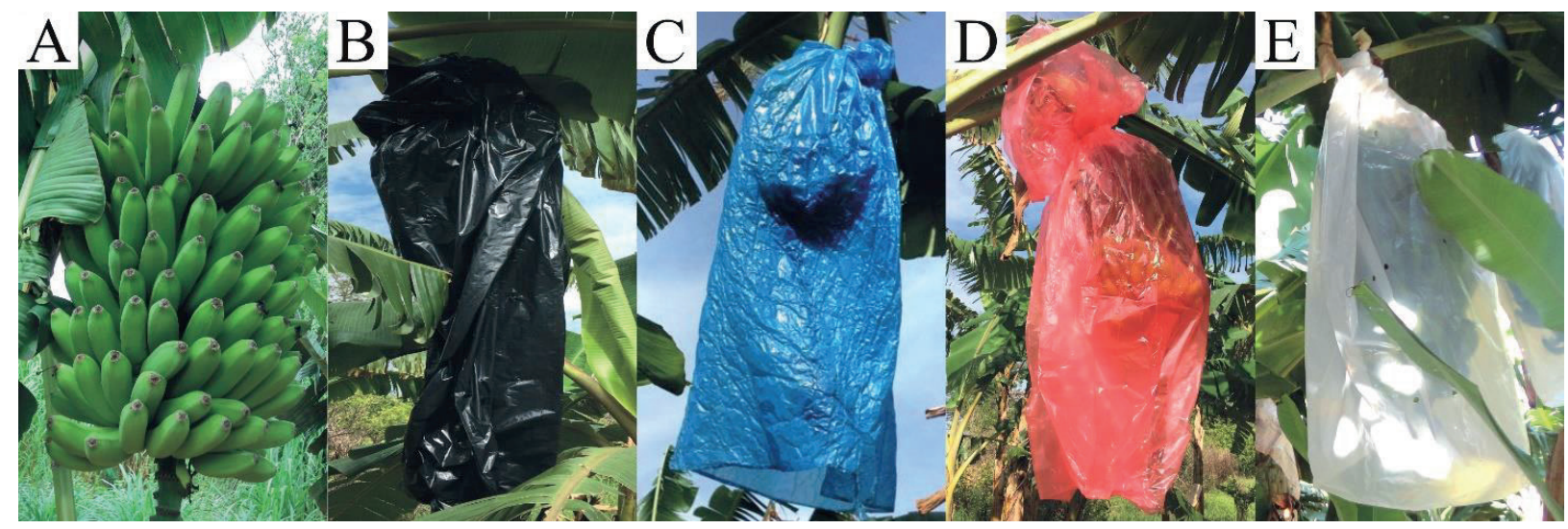

Figure 1. Uncovered bunch (A) and covered with black (B), blue (C), red (D) and white (E) polyethylene bags.

\section{Measurement of photosynthetically active radiation (PAR) inside the bags}

The photosynthetically active radiation (PAR) that exceeds in each bag and reaches the surface of the fruits was determined using the JUNIOR-PAM fluorometer (Walz), measurements were made on a clear day at $9 \mathrm{am}$.

\section{Harvest}

The bunches were harvested based on visual parameters, considering the reduction of the corner angles and totally green skin, i.e. ripening stage 1 according to the Von Loesecke scale (Companhia de Entrepostos e Armazéns Gerais de São Paulo [CEAGESP], 2006). After harvest, bunches were 
transported to the Fruit Production Laboratory, of the Horticulture Department (FCA/UNESP), where they were evaluated for thrips damage, anthracnose incidence and crop yield.

The time period from bunch covering until harvest and plant yield

The number of days from bagging the banana bunches until harvest was measured in each treatment. Furthermore, plant yield was based on the bunch fresh mass (without rachis) that could be marketed.

\section{Thrips damage and anthracnose incidence}

To measure the damage caused by thrips (Frankliniella brevicaulis), all lesions were counted in a circular area of $2.85 \mathrm{~cm}^{2}$ of each fruit immediately following harvest, by focusing on the most intensity areas of the fruit (Figure 2A). For the injuries caused by the insect, evaluations were carried out on the first, fifth, ninth and last banana hand of the bunch. In addition, by the average of the scores observed on the hands of the bunch, the severity was classified as non-defective (less than 5 scores) (Figure 2B), mild (5 to 14 scores) (Figure $2 \mathrm{C}$ ) and serious (more than 15 scores) (Figure 2D), according to the parameters established by the Banana Classification Norms of the Integrated Fruit Program of São Paulo's wholesale produce market (CEAGESP, 2006).
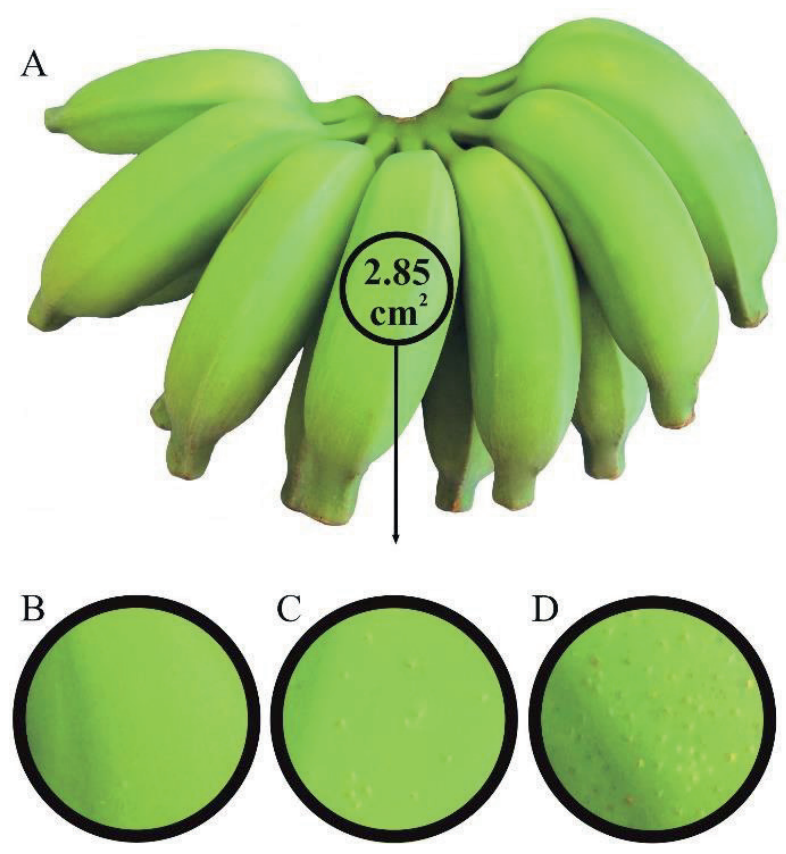

Figure 2. Data visualisation of the injury areas caused by thrips (A), fruits without injuries (B), mild injuries (C) and serious injuries (D). 
Moreover, we evaluated the injuries caused by the severity of anthracnose (Colletotrichum musae) in the percentage areas on the first, fifth, ninth and last hand of the banana bunches, counted from the apical part of the rachis, on the two fruits on the right, two in the middle and two on the left, totaling six fingers per hand.
The evaluation of anthracnose severity was only performed at once, when fruits were fully yellow, according to the Von Loesecke scale (CEAGESP, 2006). In this way, the severity of anthracnose was established in a visual score system, according to diagrammatic scale for anthracnose incidence in bananas. This scale represents the percentage of the fruit skin area with disease symptoms ranging from $0 \%$ to $64 \%$ of the injured area (Moraes, Zambolim, \& Lima, 2008) (Figure 3).

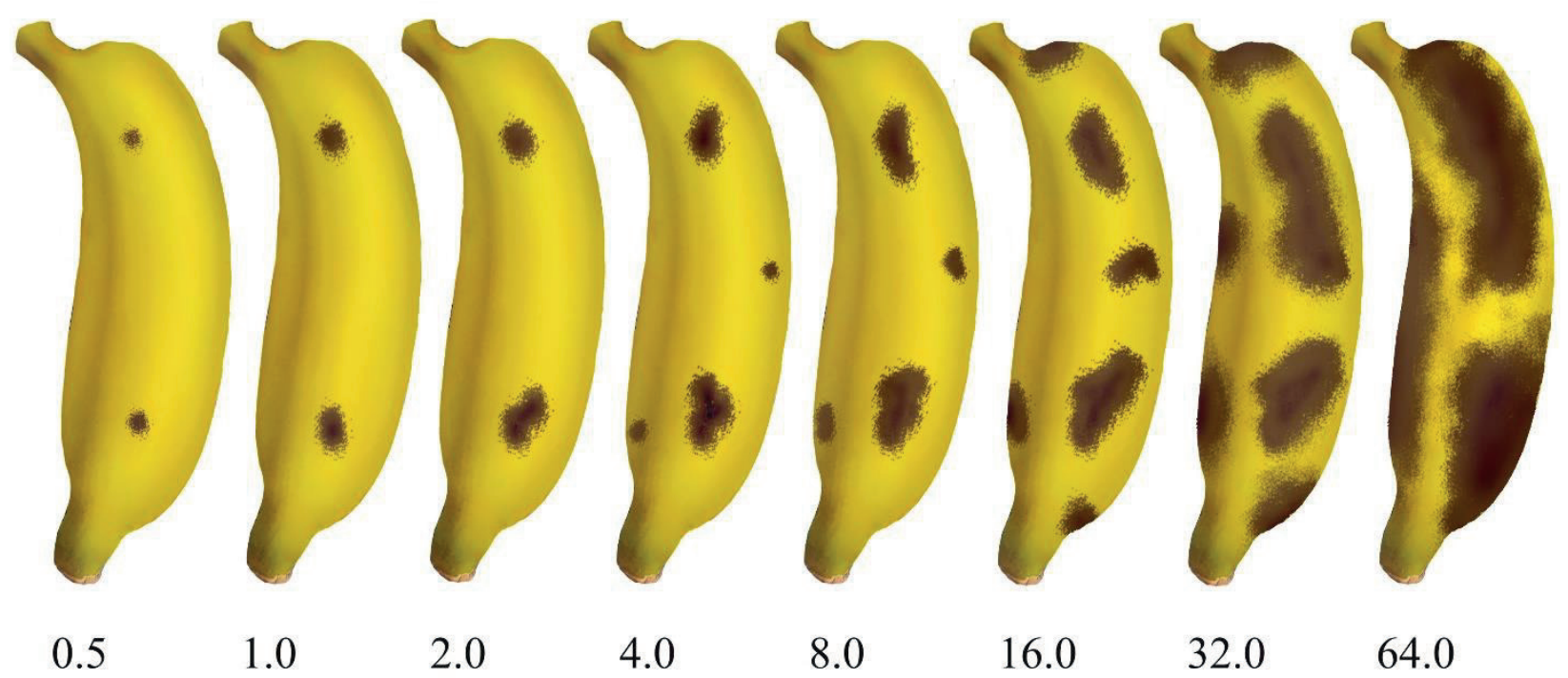

Figure 3. Diagrammatic scale for anthracnose incidence in bananas where values correspond to the percentage of fruit area damaged.

Source: Adapted by the authors from Moraes et al. (2008).

\section{Experimental design and statistical analysis}

A randomized block design was setup with five replicates (4 plants per plot), to analyse the number of days between ploughing and harvesting, as well as plant yield. To assess the damage caused by thrips and the incidence of anthracnose, the factor 'banana hands position on the bunch' was added to this design; thus, a $5 \times 4$ factorial setup (bag colours and control $\times$ banana hands position).

The $\mathrm{F}$ test was used in the analysis of variance to detect the difference between factors. When a significant difference was found for the sources of variation, the Scott-Knott test (5\% probability) was used to compare the treatment means for each variable. The data expressed as a percentage were submitted to the arc sine $\sqrt{ }$. $x / 100$.

\section{Results and Discussion}

\section{PAR inside the bags}

The descending order of PAR intensity in this study was uncovered (control), red, blue, white and black (Figure 4). The colours in the polyethylene bags acts as a filter to the photosynthetically active radiation (PAR), as designates the spectral range (wavelength) of solar radiation from 400 to 700 
nanometers in the photosynthesis. Although it that reaches the surface of the bags depends on works as a radiation filter, the intensity of the light season, growing region and spacing between plants.

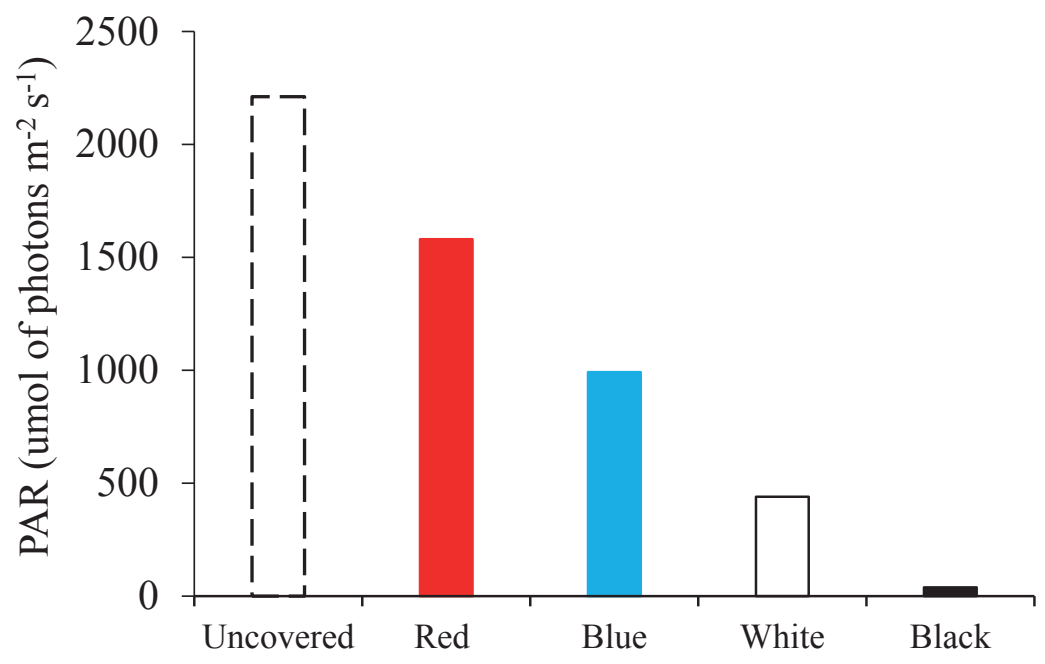

Figure 4. Photosynthetically active radiation (PAR) measured inside coloured polyethylene bags and uncovered bunches surface of banana 'BRS Conquista'.

The time period from bunch covering until harvest and plant yield

For white and black bags, results showed a reduction in the average number of days, such as 114 (white bags) and 115 days (black bags) from bunch covering until harvest; therefore, a reduction of 33 and 32 days when compared to the control (147 days). Nevertheless, the red and blue bags had an interval of 137 and 136 days, but not differing statistically from the control (Figure 5A). In other words, the bags with the shortest interval between bunch covers and harvest were those that promoted the lowest PAR. Moreover, an indicative would be the predominance of great thermal radiation that accelerated fruit ripening. The choice of color for the plastic bags depends on the producing region and the season of the year in which it is carried out, e.g. blue covers are preferred at high altitudes in the Canary Islands (PROMUSA, 2018). 

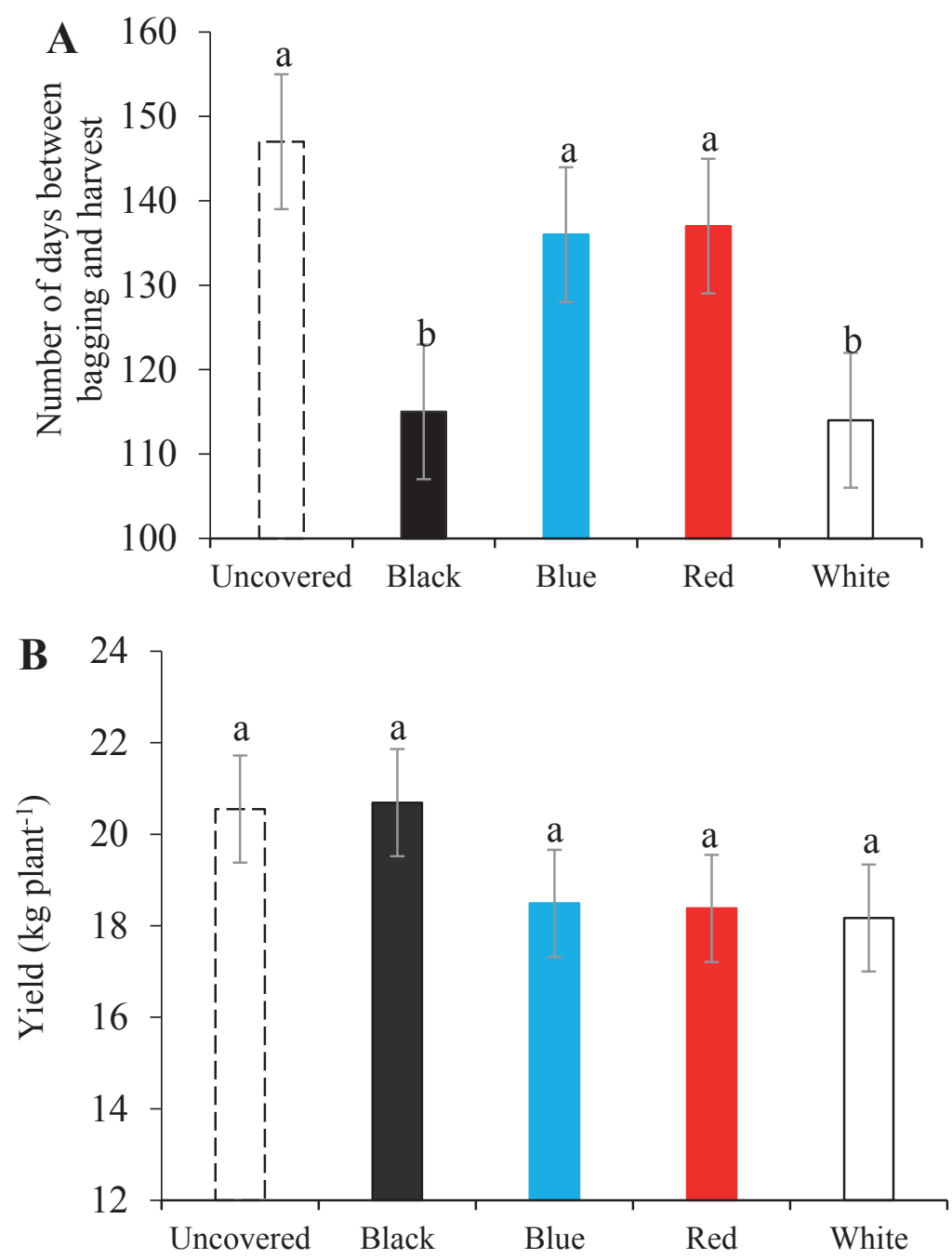

Figure 5. The period from bunch covering until harvest (A) and plant yield (B) of banana 'BRS Conquista' subjected to different polyethylene bag colours.

Means followed by the same letter are not significantly different by the Scott-Knott test at $5 \%$ of probability.

Error bars represent the standard error of the mean $(n=4)$.

According to Vargas-Calvo and Valle-Ruiz (2011), a microclimate is created inside of the bags, which maintained high temperatures, and in consequence avoiding the damage caused by the cold temperatures in subtropical regions, as in the present study. The aforementioned authors said that temperature can increase on average of $0.5^{\circ} \mathrm{C}$ inside of the bags within $24 \mathrm{~h}$, depending on the growing site. Still this increase can reach up to $7^{\circ} \mathrm{C}$ in the hottest hours of the day. This microclimate reduces for up to 4-14 days the time period from bagging the bunches until harvest, depending on the bag type and weather conditions (Santosh et al., 2017); therefore, findings in the present study are consistent with previous studies.

However, the overall literature does not recommend this practice at low elevation areas. This study occurred at high elevations; therefore, banana bunch covers should be recommended, since it increased the filling degree, which may 
have lowered the emergence to harvest interval (PROMUSA, 2018). According to Sarkar, Sarkar, Saha and Biswas (2016), emergence to harvest interval decreased to 8 days in covered bunches (124.79 days) when compared to control (133.14 days) in West Bengal, India. In tropical conditions, Moreira (2008) found that there was no bagging influence on this variable in the state of Amazonas, Brazil.

In field, different coloured bags did not interfere with the productive yield of the banana plants. On average, all treatments produced about $19.26 \mathrm{~kg}$ per plant (Figure 5B). It has commonly been assumed that the number of fingers per hand and the number of hands is directly related to the plant yields, that is, genetically defined; therefore, weather conditions and cultural management only influence until the moment of inflorescence emission. Furthermore, banana bunch cover does not interfere, since is performed after the inflorescence emission.

Similarly, Costa, Scarpare and Kluge (2002) reported that bunch covering did not increase in bunch weight, length and diameter of 'Nanicão' banana fruits in subtropical regions. Also, Moreira (2008) found in 'Nanicão 2001' that the number of hands, weight of the second hand, peel thickness, number of fingers per hand and fingers length were not affected by covering the bunches in the state of Amazonas, Brazil.

On the contrary, Sarkar et al. (2016) and Muchui et al. (2010) reported favourable outcomes for bunch covering in cv. Malbhog and Williams, respectively; with an increase in the weight of banana fruits, as the temperature inside the bag increased (PROMUSA, 2018). Regarding the effects of bunch covering on productive factors, the divergent results may depend on the crop location, since latitude, weather conditions, season of the year and thermal amplitude between day and night are also determining factors during the ripening of fruits at the expense of fruit production.

\section{Lesions caused by flower thrips}

There was a significant interaction between polyethylene bag colours and the banana hands position on the bunch. Therefore, thrips lesions occurred at unlike intensities according to different polyethylene bag colours and the hands positions on the bunch. However, regardless of the hands position on the bunch, the highest injuries incidence was found in the uncovered bunches (Table 1).

\section{Table 1}

Lesions scored in the first, fifth, ninth and last banana hands on the bunch of the 'BRS Conquista' subjected to covering

\begin{tabular}{cccccc}
\hline Treatments & First Hand & Fifth Hand & Ninth Hand & Last Hand & Severity \\
\hline Control (uncovered) & $18.35 \mathrm{Aa}^{*}$ & $19.63 \mathrm{Aa}$ & $20.30 \mathrm{Aa}$ & $22.00 \mathrm{Aa}$ & serious \\
White bag & $9.90 \mathrm{Cb}$ & $8.53 \mathrm{Cb}$ & $9.25 \mathrm{Bb}$ & $14.93 \mathrm{Ba}$ & mild \\
Black bag & $12.73 \mathrm{Ca}$ & $8.20 \mathrm{Cb}$ & $9.55 \mathrm{Bb}$ & $12.93 \mathrm{Ba}$ & mild \\
Red bag & $14.60 \mathrm{Ba}$ & $11.33 \mathrm{Bb}$ & $10.25 \mathrm{Bb}$ & $12.15 \mathrm{Bb}$ & mild \\
Blue bag & $11.78 \mathrm{Ca}$ & $11.08 \mathrm{Ba}$ & $11.43 \mathrm{Ba}$ & $11.43 \mathrm{Ba}$ & mild \\
\hline \multicolumn{5}{c}{$\mathrm{CV}(\%)=16.79$} \\
\hline
\end{tabular}

* Means followed by the same lowercase letter within columns (banana hands position on the bunch) and uppercase within lines (polyethylene colours) do not differ statistically from each other by the Scott-Knott test at 5\% probability. 
When we assessed the first banana hand on the bunch, the ones that were covered in white, black or blue polyethylene bags showed an average less damage. Moreover, the fifth hand on the bunch covered in white and black colours presented the lowest damage averages. Besides the ninth and last banana hands on the bunches had no difference in damage to the other covered bunches. Thus, the white and black polyethylene bags were more efficient in controlling and reducing the damage in banana bunches caused by thrips, though all of polyethylene colours have reduced the damage when compared to the uncovered bunches (Table 1).

By assessing the treatments individually of each hand, the control and the blue cover did not show any difference for the hand position on the bunch. However, white bag showed the highest damage average in the last hand, while red cover was the most attacked in the first hand. Furthermore, the black bags on first and last hand were more attacked by thrips. In general, the use of white and red polyethylene bags allowed to obtain a larger portion of the bunch (number of hands per bunch) with less thrips attack, especially the white one. Regarding severity, it was found that covering the bunches with bags of any color caused mild injuries, while the uncovered bunches were serious (Table 1).

Similarly, Sakai (2015) observed many lesions caused by thrips in uncovered bunches in an experiment with banana cv. Nanicão; the insect infestation was significantly lower $(1.8 \%)$ in covered bunches than uncovered ones (98.5\%). Moreover, these authors found that using white polyethylene bag promoted less thrips damage to the fruits. The results reinforced the relevance of covering the bunches as an alternative to control flower thrips, since there are almost twice as many thrips lesions in the uncovered bunches. Producers will benefit from this information whether they are looking after differentiating management practices, aiming at a specific consumer market, such as organic agriculture or even export. Considering that
Brazil is not intensively engaged in the international market of banana, because of the low quality of the fruits (Centro de Estudos Avançados em Economia Aplicada, 2017); but bunch covering will enable the production of high-quality fruits.

Regarding the differences found in different bag colours; notably, the herbivorous insects' vision is attracted to some wavelengths, hue, brightness and saturation, which are obtained through the light. Besides that, there are other ways in which the insect is directed to the host, through the perceived quality of the spectrum, size and shape of the objects. When insects travel to the host, they can perceive either chemical or visual stimuli (Santosh et al., 2017). Therefore, the smallest attack observed in bunches covered with white bags may be associated with the less attractive nature of this bag colour for thrips.

The largest injuries cause by thrips in the last banana hands of covered bunches are due to the insect's habit of lodging in the male inflorescence, where they feed and oviposit (Fancelli \& Mesquita, 2012), that is, close to the lower end of the bunch. On the other hand, the biggest injuries in the first hand of the covered bunches are because of the location of banana hands at the point where the bag was tied. This is explained by the morphological characteristics of thrips, that is, a long, narrow, insect about $1 \mathrm{~mm}$ long, which were likely to have penetrated through the bag (Santosh et al., 2017). While insect had an easy access to all banana hands of bunches when no bags were used, explaining the high injury in all hands from uncovered bunches.

\section{Anthracnose incidence}

There was no significant interaction between polyethylene bag colours and banana hands position on the bunch. Results showed the severity of anthracnose occurred homogeneously throughout the bunch, regardless of the banana hands position. The highest incidence and severity of anthracnose was observed in the uncovered bunches. Moreover, 
the black polyethylene bag presented the highest percentage of injuries among the covered bunches. On the contrary, the lowest percentage of injuries was observed in the bunches covered with white, red and blue bags (Figure 6).

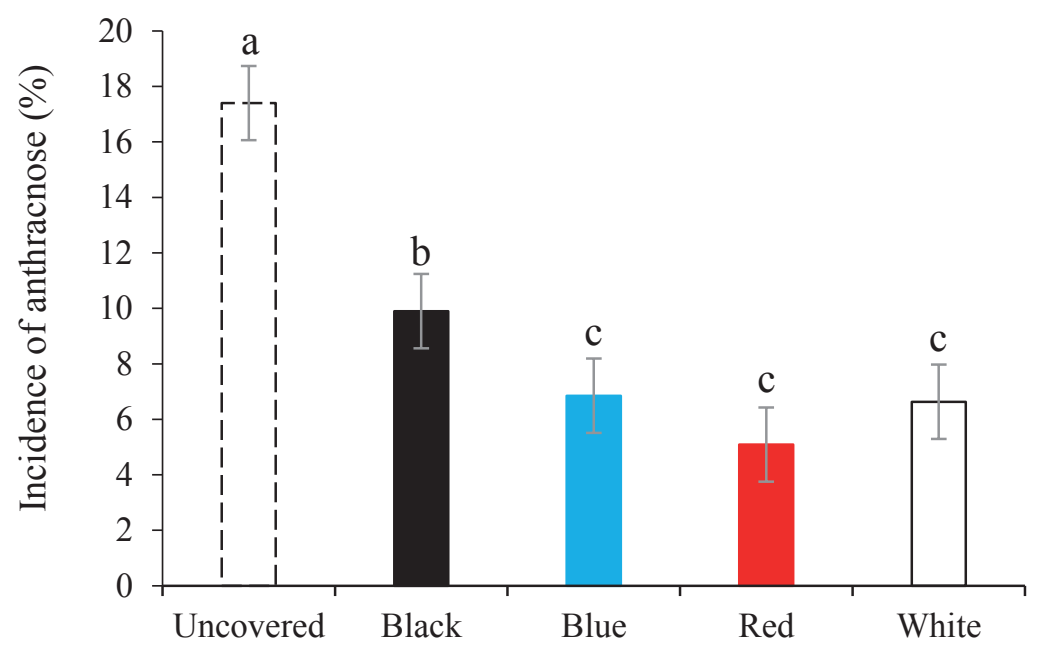

Figure 6. Incidence of anthracnose (\%) in bunches of 'BRS Conquista' subjected to different polyethylene bag colours.

Means followed by the same letter are not significantly different by the Scott-Knott test at $5 \%$ of probability.

Error bars represent the standard error of the mean $(n=12)$.

The incidence of anthracnose occurs in uncovered bunches throughout the development of the fruits in the field. Although anthracnose mainly happens throughout the ripening stage, the infection starts in the field, when the fruits are infected by the conidia (causal agent) (Prusky \& Kobiler, 2012). Therefore, pathogen explores several routes to penetrate the host, such as wounds, natural openings and direct violation of the cuticle. This allows the pathogen direct access to the green tissue, remaining quiescent until the fruit ripening process begins. Finally, becoming active and causing anthracnose under certain conditions, anthracnose impairs fruit quality, visual appearance and reduces shelf life (Prusky, Alkan, Mengiste, \& Fluhr, 2013).

Nevertheless, we always should consider the amount of injuries caused by thrips in uncovered bunches, since it also justifies the highest percentage of tissues injured by anthracnose. In an experiment that evaluated alternative methods to control anthracnose, Negreiros, Salomão, Pereira, Cecon and Siquera (2013) reported that fruit damage caused by insects is an important gateway to post-harvest diseases, such as anthracnose. For this reason, the covering the bunches shortly after the inflorescence emission significantly reduces the rates of infection by fungi (C. musae), allowing the production of high-quality fruits (Mirshekari et al., 2012).

Regarding the higher incidence of anthracnose in fruits from covered bunches with black polyethylene, Fragata, Sens and Sebrão (2015) mentioned that black bags absorb all wavelengths; therefore, there is an increase in temperature inside the the bag, providing a favourable microclimate to develop C. musae. Serra, Coelho, Ferraz, Montarroyos and Silva (2011) reported that the development of $C$. musae is favoured by high relative humidity and temperature. Similar results were found by Amani 
and Avagyan (2014) who reported that the disease progresses in environments with high relative humidity and temperature.

\section{Conclusion}

The covering of banana bunches did not interfere in the plant productive yield, with an average of 19.26 $\mathrm{kg}$ per plant in 'BRS Conquista'. However, the time interval between bunch covering and harvest was reduced to 114 days in white and 115 days in black polyethylene bags. Bunch covering is also efficient in controlling the flower thrips (Frankiliniella brevicaulis), as it minimized the peel damages, especially in white and red bags. Moreover, white, red and blue polyethylene bags promoted a lower incidence of anthracnose (Colletotrichum musae). Thus, it is possible to recommend covering the bunches of 'BRS Conquista' bananas with white polyethylene bags, as it efficiently controlled both thrips and anthracnose, beside lowering the time interval between bunch emergence and harvest.

\section{References}

Amani, M., \& Avagyan, G. (2014). Effect of polypropylene bunch cover on fungal diseases control of banana (Musa acuminata L.) in Iran. International Journal of Farming and Allied Sciences, 3(10), 1054-1057.

Brown, P. R., Mc William, A., \& Khamphoukeo, K. (2013). Post-harvest damage to stored grain by rodents in village environments in Laos. International Biodeterioration \& Biodegradation, 82(1), 104-109. doi: 10.1016/j.ibiod.2012.12.018

Centro de Estudos Avançados em Economia Aplicada (2017). Exportações recuam 61\% em 2017. (Relatório de Pesquisa, 2017). Piracicaba, SP.

Companhia de Entrepostos e Armazéns Gerais de São Paulo (2006). Programa brasileiro para a modernização da horticultura e produção integrada de frutas. Normas de classificação de banana. Recuperado de http://www.ceagesp.gov.br/wpcontent/uploads/2015/07/banana.pdf

Costa, J. N. M., Scarpare, J. A., F ${ }^{\circ}$, \& Kluge, R. A. (2002). Efeito do ensacamento de cachos de banana 'Nanicão' na produção e no intervalo entre inflorescência e colheita. Pesquisa Agropecuária Brasileira, 37(11), 1575-1580. doi: 10.1590/S0100204X2002001100008

Cunha, A. R., \& Martins, D. (2009). Classificação climática para os municípios de Botucatu e São Manuel-SP. Irriga, 14(1), 1-11. doi: 10.15809/ irriga.2009v14n1p1-11

Embrapa Empresa Brasileira de Pesquisa Agropecuária (2006). Sistema brasileiro de classificação de solos. (2a ed.). Rio de Janeiro, RJ.

Fancelli, M., \& Mesquita, A. L. M. (2012). Pragas e métodos de controle. In L. Gasparotto, \& J. C. R. Pereira (Eds.), A cultura da bananeira na região Norte do Brasil (pp. 638-730). Brasília: EMBRAPA Informação Tecnológica. Recuperado de http:// livimagens.sct.embrapa.br/amostras/00083880.pdf .

Food and Agriculture Organization (2017). Production crop. Retrieved from http://faostat3.fao.org/browse/ q/qc/e.

Fragata, F., Sens, M., \& Sebrão, M. Z. (2015). Influence of the colour of polyurethane paints in the absorption and heat dissipation. Corrosão e Protecção de Materiais, 34(2), 53-59. Retrieved from http://www. scielo.mec.pt/pdf/cpm/v34n2/v34n2a03.pdf

Mirshekari, A., Ding, P., Kadir, J., \& Ghazali, H. M. (2012). Effect of hot water dip treatment on postharvest anthracnose of banana var. Berangan. African Journal of Agricultural Research, 7(1), 6-10. doi: 10. 5897/AJAR11.056

Moraes, W. S., Zambolim, L., \& Lima, J. D. (2008). Quimioterapia de banana 'prata anã' no controle de podridões em pós-colheita. Arquivos do Instituto Biológico, 1(75), 79-84. doi: 10.1590/S0100-415820 06000100003

Moreira, A. (2008). Proteção de cachos de bananeira com sacos de polietileno nas condições edafoclimáticas do estado do Amazonas. Ciência e Agrotecnologia, 32(1), 129-136. doi: 10.1590/S1413-70542008000 100019

Muchui, M. N., Mathooko, F. M., Njoroge, C. K., Kahangi, E. M., Onyango, C. A., \& Kimani, E. M. (2010). Effect of perforated blue polyenthlene bunch covers on selected post-harvest quality parameters of tissue cultured bananas (Musa spp.) cv. Williams in Central Kenya. Journal of Stored Products and Postharvest Research, 1(3), 29-41. Retrieved from https://africaneditors.org/journal/JSPPR/full-textpdf/86398-130476 
Negreiros, R. J. Z., Salomão, L. C. C., Pereira, O. L., Cecon, P. R., \& Siquera, D. L. (2013). Controle da antracnose na pós-colheita de bananas 'prata' com produtos alternativos aos agrotóxicos convencionais.

Parisi, M. C. M., Henrique, C. M., \& Prati, P. (2015). Doenças pós-colheita: um entravena comercialização. Pesquisa \& Tecnologia, 12(2), 1-5. Recuperado de https://pt.slideshare.net/ruralpecuariapecuaria/ doenas-pscolheita-um-entrave-na-comercializao

Pereira, J. C. R., \& Gasparotto, L. (2008). BRS Conquista: nova cultivar de bananeira para o agronegócio da banana no Brasil. (p. 2). Manaus, Brasil: Embrapa Amazônia Ocidental. Recuperado de https://ainfo. cnptia.embrapa.br/digital/bitstream/CPAA-200909/21021/1/Com_Tec_60.pdf

PROMUSA (2018). Bagging/News, knowledge and information on bananas from. Recuperado de http:// www.promusa.org/Bagging

Prusky, D., \& Kobiler, I. (2012). Mechanisms modulating the activation of quiescent infections by postharvest pathogens. In S. M. A. Oliveira, S. R. O. Lins, \& A. M. G. Santos (Eds.), Avanços tecnológicos na patologia pós-colheita (pp. 275-296). Recife: Editora UFRPE.

Prusky, D., Alkan, N., Mengiste, T., \& Fluhr, R. (2013). Quiescent and necrotrophic lifestyle choice during postharvest disease development. Annual Review of Phytopathology, 51(1) 155-176. doi: 10.1146/ annurev-phyto-082712-102349

Sakai, R. K. (2015). Desenvolvimento e qualidade de frutos de banana em função da proteção física dos cachos. Tese de doutorado, Escola Superior de Agricultura "Luiz de Queiroz", Piracicaba, São Paulo, Brasil. Recuperado de https://teses.usp.br/ teses/disponiveis/11/11136/tde-22062015-171150/ publico/ Ronaldo_Kazuo_Sakai_versao_revisada. pdf

Santosh, D. T., Tiwari, K. N., \& Reddy, R. G. (2017). Banana bunch covers for quality banana production. International Journal of Current Microbiology and Applied Sciences, 6(7), 1275-1291. doi: 10.20546/ ijcmas.2017.607.155
Sarkar, S., Das, G., Sarkar, S., Saha, S., \& Biswas, S. (2016). Frontline demonstration on effect of bunch cover in banana for quality production of banana fruits. International Journal of Green Pharmacy, 10(4), 1-4. Retrieved from https://www. researchgate.net/publication/313846938_Frontline_ demonstration_on_effect_of_bunch_cover_in_banana_for_quality_production_of_banana_fruits

Serra, I. M. R. S., Coelho, R. S. B., Ferraz, G. M. G., Montarroyos, A. V. V., \& Silva, D. S. (2011). Diversidade fenotípica e patogênica de Colletotrichum, agente causal de antracnose em mangueira, e identificação de espécie. Summa Phytopathologica, 37(1), 42-51. doi: 10.1590/ S0100-54052011000100007

Smith, M. K., Langdon, P. W., Pegg, K. G., \& Daniells, J. W. (2014). Growth, yield and Fusarium wilt resistance of six FHIA tetraploid bananas (Musa spp.) grown in the Australian subtropics. Scientia. Horticulturae, 170(7), 176-181. doi: 10.1016/j. scienta.2014.02.029

Souza, M. E., Leonel, S., \& Fragoso, A. M. (2011). Crescimento e produção de genótipos de bananeiras em clima subtropical. Ciência Rural, 41(4), 587-591. Recuperado de http://www.scielo.br/pdf/cr/v41n4/ a924cr4241.pdf

Vargas, A., Valle, H., \& González, M. (2010). Effecto del color y de la densidad del polietileno de fundas para cubrir el racimo sobre dimensiones, presentatión y calidad poscosecha de frutos de banana y plátano. Agronomia Costarricense, 34(2), 269-285. doi: 10.15517/am.v22i1.8670

Vargas-Calvo, A., \& Valle-Ruiz, H. (2011). Effecto of two banana (Musa AAA) bunch covers on fruit quality. Agronomia Mesoamericana, 22(1), 81-89. doi: 10.15517/AM.V22I1.8670 
